\title{
原著 VII
}

\section{リンパ節と骨随で汇胞様増殖を示した \\ マクログロブリン血症の一例}

\author{
1)放射線医学総合研究所病院部 \\ 2) 筑波大学基礎医学系 \\ 3) 東京医科蔝科大学第一内科
}

阔邦 行 ${ }^{12}$, 森尚 義泉, 小島瑞 ${ }^{2}$ 室 橋 郁 生 ${ }^{11}$, 宮 本忠 昭 ${ }^{1)}$, 奈良信 雄 ${ }^{3)}$

（雀和58年 2 月 16 日受付)

最近われわれは，リンパ節腫大と肝脾腫をきたし， 生検上リンパ節と骨㴶に沪胞样増殖を呈したマクログ ロブリン血症 ( $\operatorname{Ig} M, \lambda$ 型) の 1 症例を経験したので 報告する。

\section{症例}

患者 34 才。男性。

主訴 全身僚念感, 発熱, 貧血。

家族歴・既往歴特記すべき事なし。

臨床経過 生来健康で, 10数回の献血時, 異常を指 摘された事はなかった。1978年10月に行った献血の際 に低比重を指摘されるも放置していた。同年12月25日 頃より全身隐急感, $37 \sim 38^{\circ} \mathrm{C}$ 台の発熱, 咳, 舅汁が出 現し，市販の風邪薬を服用したが症状の改善がみられ なかった。1979年1月6日某医を受診し, 肺炎と高度 の貧血を指摘された。同年 4 月17日ラジオアイソトー プによる髄外造血検查の目的で, 放医研病院部に紹介 された。

初唁時米粒大から小亘大のリンパ節が，䫀部・腋简 部・鼠径部に数個触れ, さらに肝が 2 横指脾が 3 横指 触知された。5月18日の検查では, 血清総タンパクは $6.4 \mathrm{~g} / \mathrm{d} \ell$ であったが, このうち $\gamma$-グロブリンが 27.1 \%で IgM が1,130mg/de と增加を示した。闹時に免 灾電気泳動上 IgM，入型のM成分を示す沈降線を琶 めた。血清相刘粘程度は汇常で，血清中パイログロブ リンは陽性であったが，尿中ベンス・ジョーンズ蛋白 は陰性であった。1981年 5 月 6 日の検査で, 血清 IgM 㒹は最高 $2,800 \mathrm{mg} / \mathrm{d}$ と増加したが, 化学療法（サイ
表 1 Laboratory Findings $(1979-5-18)$

ESR
Peripheral blood
RBC
Hb.
Hct.
platelets
Reticulocytes
WBC
Atypical mononuclear cells
Routeaux formation
Coagulation study
Bleeding time
Coagulation time
Prothrombin time
Serum protein
Total protein
Albumin
$\gamma-$ globulin
Ig G
Ig M
Ig A

Immunoelectrophoresis pattern:

Sia water test

Pyroglobulinemia

Cryoglobulinemia

Urine

Protein

$28 / 59 \mathrm{~mm}$

$361 \times 10^{4} / \mathrm{mm}^{3}$

$12.6 \mathrm{~g} / \mathrm{de}$

$38 \%$

$2.9 \times 10^{4} / \mathrm{mm}^{3}$

$12 \%$

$5,200 / \mathrm{mm}^{3}$

(-)

(-)

$4 \mathrm{~min}$.

$10 \mathrm{~min}$.

10.8 sec.

$6.4 \mathrm{~g} / \mathrm{de}$

$44.6 \%$

$27.1 \%$

$1,340 \mathrm{mg} / \mathrm{de}$

$1,130 \mathrm{mg} / \mathrm{de}$

$65 \mathrm{mg} / \mathrm{de}$

$\mathrm{M}$ bow

(IgM, $\lambda$-type)

$(-)$

(t)

(-)

(士)

$\begin{array}{ll}\text { Bence-Jones Protein } & ( \pm) \\ \text { Sugar } & (-)\end{array}$

Serologic test

Wa-R

(-)

Cold agglutination $\quad 1: 64$

ASLO

CRP

RA $\quad(+)$

Coombs' test (direct)

(indirect) (-) 
表 2 Laboratory Findings

\begin{tabular}{lrrrr}
\hline Serum Protein & 1979 & 1980 & 1981 & 1981 \\
& $6-29$ & $5-8$ & $5-6$ & $11-17$ \\
T.P. $(g / d \ell)$ & 7.0 & 7.1 & 8.3 & 8.1 \\
Albumin $(\%)$ & 54.4 & 60.4 & 52.9 & 67.0 \\
$\gamma$-globulin(\%) & 25.6 & 19.2 & 27.6 & 10.9 \\
IgG $(m g / d \ell)$ & 1,240 & 1,040 & 1,175 & 850 \\
IgM $(m g / d \ell)$ & 1,520 & 630 & 2,800 & 345 \\
IgA $(m g / d \ell)$ & 174 & 126 & 130 & 100 \\
\hline
\end{tabular}

クロフォスファマイド・オンコビン・アドリアマイシ ン・プレドニゾロン）に反忘し，1981年12月25日には $\operatorname{IgM}$ 值が $115 \mathrm{mg} / \mathrm{d} \ell$ と減少した。リンパ節腫大と肝脾 腫も縮少傾向を示し，1983年 1 月現在経過良好であ る。おもな臨床検查成績は表 1 と 2 に示す。

末梢血液所見 赤血球数は，208万～361万と中等度 の減少を示し，正色素性正球性貧血がみられた。白血 球数は, 3,700〜9,200で, リンパ球の增多はみられなか った。むた末血中には, 異型性のあるリンパ球様細胞 や形質細胞様細胞は, 経過を通して認められなかった。

骨鹃塗沫像骨咀は軽度低形成から正形成であっ た。塗沫標本でリンパ球様細胞あるいは形質細胞様細 胞が，数10個集簇して認められた。これらの細胞は， 直径 $9 \sim 13 \mu$ で，核は円形ないし類円形を示し胞体中 心部に位置し，クロマチンに富み，塊状あるいは粗剛 な網工を形成していた。胞体は好塩基性を示すが，顆 粒を含有していなかった。

初回リンパ節生検像（1979年 5 月21日生検）鼠径部 より小指頭大のもの 1 個と大豆大のもの 2 個のリンパ 節が探取された。これらのリンパ節には沪胞様增殖策 が，皮質髄質の区別なくリンパ節全体に認められた （写真 1 ）。沪胞様構造を形成している増殖細胞は, 形 態上 2 種類に大別された。一方は，異型性の乏しい円 形核を有する小リンパ球様細胞であり, 汇胞様增殖单 の中心部に認められた（写真2a）。も5一方の細胞は， 同じく異型性に乏しい形質細胞様であって, 沪胞様増 殖栄の辺縁部ないし周辺部に認められた（写真2b）。 核内および胞体内封入体は認められなかった。リンパ 節の被膜周囲には, 上記の増殖細胞は認められず, 正 常小型リンパ球と好酸球を主体とする炎症細胞浸潤が みられた。

Taylor らの PAP 法12) による胞体内免疫グロブ リン染色では, 抗 IgM 血清ならびに抗 $\lambda$ 血清で, 晹 性像が, 沪胞様增殖巣辺縁部と周辺部の形質細胞様細 胞に喼められた。また, 陽性像は少数ながらも, 汇胞 様増殖栄中心部の小リンパ球様細胞にも認められた (写真 3)。なお, 抗 IgG, A, D, 抗 $\kappa$ 血清で陽性を
示す細胞が, 汇胞様増殖单辺縁部ないし周辺部で, 僅 かながら混在していた。

第 2 回リンパ節生検像（1981年4月 6 日生検）第 2 回生検リンバ節は，頸部から小豆大のもの 2 個が採取 された。これらリンパ節は, 組織学的に初回の時とほ 添同じ所見であった。すなわちリンパ節は沪胞様增殖 を呈しており，増殖細胞は，沪胞様増殖采中心部では 前回同椂異型性の乏しい小リンパ球樣細胞であった。 しかし初回生検像と異なり, 沪胞様増殖夈中心部に少 数の芽球様細胞が小リンパ球様細胞にまじって，そし て沪胞样増殖巣辺縁部には多数の芽球様細胞が，形質 細胞様細胞に混じって認められた（写真 4)。これら 芽球様細胞は，クロマチンに乏しい大型核を有し，间 瞭な核小体を有する細胞であった。

PAP 法では, 初回生検像と同様に, 抗 IgM 血清 ならびに抗 $\lambda$ 血清で, 強陽性像が，沪胞様構造辺縁部 の形質細胞様細胞にみとめられ，辺縁部の牙球様細胞 も前者ほどは強くないが，陽性像がみとめられた。ま た中心部の小リンパ球様細胞にも陽性像が散見され た。加えて抗 IgM 血清で強陽性を示す核内封入体が, 少数ではあるが牙球様細胞と思われる細胞内にみとめ

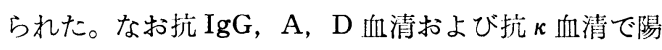
性を呈する細胞は, 初回の生検と比べて極めて少数で あった。

電顕酵素抗体法 ${ }^{13)}$ では, 陽性像が抗 IgM 血清で, 沪胞様增殖栄中心部に分布する小リンパ球様細胞の核 膜槽と桿状の粗面小胞体に一致してみとめられた（写 真 5 )。更に沪胞様增殖单辺縁部の芽球様細胞（写真 6) や形質細胞様細胞（写真 7) 飞も，陽性像がみと められた。

骨髄凝塊パラフィン切片標本(1980年10月 7 日穿刺, 有核細胞数 67,000$) \mathrm{HE}$ 染色上骨鄙には, リンパ節问 様洰胞様增殖巢が散見された。PAP 法では陽性像が， 沪胞様増殖夈辺縁部に分布する多数の形質細胞様細胞 にみとめられ，少数ながら沪胞様増殖策中心部の小リ ンパ球様細胞にもみとめられた (写真 8)。なお1981年 9 月 1 日（有核細胞数 114,000$), 1982$ 年 1 月 12 日（有 核細胞数 168,000$)$ に行った骨睢穿刺時にも，同様の 所見が得られた。

\section{考察}

本症例は 2 度のリンパ節生検上，小リンパ球様細胞 の沪胞様増殖が認められた。增殖細胞は小リンパ球と 同大かそれよりやや大きく，類円形核を有し，核のく びれを示さないことなどから，リンパ沪胞とくに一次 
沪胞を構成する細胞由来の覀性リンパ腫と考えられ た。沪胞様增殖巣辺縁部および周辺部には多数の形啠 細胞様細胞がみとめられた。光顕醉素抗体法 (PAP 法）ならびに電顕酵素抗体法で沪胞様增殖栄内の小リ ンパ球様細胞の一部, および沪胞様增殖柴辺縁部なら びに周辺部の形質細胞様細胞の大部分が，抗 IgM， $\lambda$ 血清で陽性像を示したことから，これらの形質細胞 様細胞も汇胞様增殖栄内の增殖細胞と同一系統の腫垸 細胞と考えられた。

すなわち本症例では, 一次沪胞由来の小リンバ球が 腫焬性に增殖して沪胞様構造を形成し，腫煌細胞が成 熟するにつれて沪胞様增殖巣辺縁部ならびに周辺部に 移動し，免疫グロブリン産生細胞となり，血清中に免 疫グロブリン $(\operatorname{IgM}, \lambda)$ を分泌してマクログロブリン 血症を星するようになったと考劣ることが出来る。從 来より well-differentiated lymphocytic, diffuse タイプ(Rappaport8)) のリンパ腫がしばしばマクロ グロブリン血症を呈することはよく知られた事実3)4 5) 7) 8) 11) 14)であることから, 本例はこのタイプのリ ンパ凬の初期像の可能性を亦唆するものと考兄た。

Moore ら日) は免股電気泳動法を行った覀性リンパ 牌 678 例を検討した結果, 結節性リンパ腫とホジキン 病の症例にはマクログロブリン血症を呈する症例はな かったが,びまん性リンパ腫の3.6\%の鉦例にマクログ ロブリン血症を想めたと報告している。我々が調べた 笓囲では，本症例と酷似した症例の報告が Kim ら2) によってなされている(1973年)。この症例では組織学 侧に well-differentiated lymphocytic, nodular タイプのリンパ腫と診断され，血清中のM成分は IgM

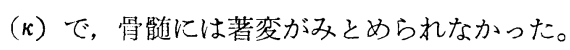

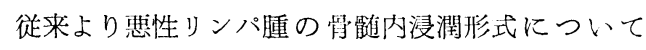
は，結節性㧍よびびまん性浸潤が知られている ${ }^{9)} 。 マ$

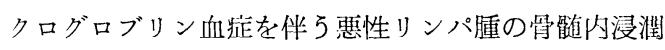
像については，びまん性よりも結節性増殖様式を示す ことが幾分多いという報告 ${ }^{10)}$ があり，まれではある が一次汇胞様の增殖様式を示すという論文 1) 14) もあ

\section{文}

1) Dutcher, T.F. and Fahey, J. L.: The histopathology of the macroglobulinemia of Waldenström. J. Natl. Cancer Inst. 22:887-901, 1959.

2) Kim, H., Heller, P. and Rappaport, H.: Monoclonal gammopathies associated with lymphoproliferative disorders: a morphologic
る。本㫌例の肖随所見は生検リンパ節と極めてよく一 致していた。すなわち小リンパ球様細胞からなる沪胞』 様増殖柴が骨搉内に点在し, 沪胞様構造辺縁部には形 筫細胞様細胞がみとめられた。更に骨娟有の醅素抗体法 (PAP 法)でリンパ節同様抗 $\operatorname{IgM}, \lambda$ 血清で, 大部分 の形質細胞様細胞と一部の小リンパ球様細胞に陽性像 が得られた。従ってこの胃髄像もリンパ節における胛 瘍細胞の增殖パターンを模做したものと解釈される。

第 1 回の生検時にはすでに血清中に IgM，入タイ プのM成分が出現していたが, リンパ節とくに沪胞様 堌殖巣周辺部には, IgM, 入 陽性細胞とともに IgG, A，D， $\boldsymbol{\kappa}$ 陽性細胞が種々の割合で混在していた。第 2 回の生検時には陽性細胞の大部分は $\operatorname{IgM}, \lambda$ で陽 性であった。このような所見は, 単クローン性免度グ ロブリン血症の発現にあずかる增殖細胞が，多クロー ン性增殖から単クローン性增殖へと移行しつつある過 程を表わしているとも考えられるが，単に反応性の形 䓄細胞が混り合った可能性も否定できない。

2 回目の生検時には, 芽球様細胞が, 主として沪胞

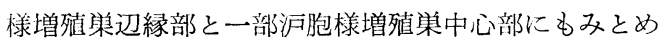
られた。従って本症例は化学潦法によく反応し、リン パ節腫脤と旰脾腫の縮少および血清 IgM 値などの臨 床症状の改善をみたものの, 形態学的にはより一圆翼 型の強い細胞増殖に変ってきたものと考号られる。こ のような形態像の変化も, マクログロブリン血症の進 屡状況を知る上で貴重であり, 臨床像の経過とともに 充分の精查観祭が必要であろう。

\section{結語}

リンパ節腫大と肝脾腫をきたし，生検上リンパ節 と学喵迶に汇胞様增殖を呈したマクログロブリン血症 (IgM, $\lambda$ 型) の 1 症例を報告した。本症例は, 光顕像 および䤏素抗体法所見より，リンパ沪胞とくに一次沪 胞を構成する細胞由来の悪性リンパ腫であると考光た。

稿を終るにあたり，千葉健生坊院内科花井透先生の 御協力に深謝致します。

\section{献}

study. Am. J. Clin. Path. 59:282-294, 1973.

3) Kojima, M., Mori, N. and Shimamura, K.: Electron microscopical study on cytoplasmic immunoglobulin of B cell lymphoma. Acta Haematol. Jpn. 43:971-978, 1980.

4) Kojima, M. and Mori, N.: Immunohistological analysis of malignant lymphomas of $\mathrm{B}$ cell 
origin. Acta Pathol. Jpn. 32 (Suppl. 1):155 169, 1982.

5) Lukes, R.J. and Collins, R.D.: Immunologic characterization of human malignant lymphomas. Cancer 34:1488-1503, 1974.

6) Moore, D.F., Migliore, P. J., Shullenberger C. C. and Alexanian, R.: Monoclonal macroglobulinemia in malignant lymphoma. Ann. Intern. Med. 72:43-47, 1970.

7) Mori, N., Abe, M. and Kojima, M.: Study of malignant lymphomas from the aspect of immunoglobulin production. Acta Pathol. Jpn. 29(5):705-722, 1979.

8) Rappaport, H.: Tumor of the hematopoietic system. Atlas of tumor pathology, Section III, Fasc. 8, A.F.I.P., Washington, D.C., 1966.

9) Rywlin A.M., Ortega, R.S. and Dominguez, C.J.: Lymphoid nodules of bone marrow. Normal and abnormal. Blood 43:389-400, 1974.
10) Rywlin A.M., Clivantos, F., Ortega, R.S. and Dominguez, C.J.: Bone marrow histology in monoclonal macroglobulinemia. A m. J. Clin. Path. 63:769-778, 1975.

11）柴田昭，小野寺清寿，三浦它ら：原発性マクログ ロブリン血症一自験例 4 例の検討と本邦報告例の文 献的考察一最新医学 24:657-677, 1975.

12) Taylor, C.R.: Immunocytochemical methods in the study of lymphoma and related conditions. J. Histochem. Cytochem., 26:496512, 1978.

13) Tsunoda, R., Terashima, K., Takahashi, K. and Kojima, M.: An ultrastructural study with enzyme-labeled antibody technique on immunoglobulin-containing cells in human tonsils, especially in germinal centers. Acta Pathol. Jpn., 28:53-75, 1978.

14）山口和克：日本の Macroglobulinemia-苪珄! 総合臨林22 (8):1616-1628, 1973.

\section{写 真 説 明}

1. 初回リンパ節生検像（1979年 5 月 21 日生検）。沪胞様增殖栄がリンパ節全体にみられる。HE染色。 $\times 40$ 。

2. 闾上。 $\mathrm{HE}$ 染色。 $\times 400$ 。 a. 沪胞様増殖巣中心部。小リンパ球様細胞がみられる。 b. 汇胞様増殖栄周辺部。 形質細胞様細胞がみられる。

3. 同上。PAP 染色による胞体内免㡯グロブリン（抗 $\operatorname{IgM}$ 血清）染色。多数の陰性細胞が，沪胞様增殖果辺線 部および周辺部にみられ，少数ながらも陽性細胞が，汇胞様増殖集中心部にもみとめられる。 $\times 100 。$

4. 第 2 回目のリンパ節生検像（1981年 4 月 6 日生検）。沪胞様増殖泉辺縁部。芽球㥞細胞がみられる。HE染任。 $\times 200$ 。

5. 同上。電顕醭素抗体法。沪胞様増殖单中心部にみられた小リンパ球様細胞。核膜槽および粗面小胞体に一致し て，抗 IgM 血清で陽性像がみられる。×13,000。

6. 同上。電顕醉素抗体法。汇胞様增殖巣辺縁部にみられた芽球様細胞。一部の粗面小胞体に一致して, 抗 IgM 血清で陽性像がみられる。 $\times 8,000 。$

7. 同上。電顕酵素抗体法。汇胞様增殖坚辺緣部にみられた形質細胞様細胞。粗面小胞体に一致して, 抗 IgM 血 清で陽性像がみられる。×11,000。

8. 骨榷凝塊パラフィン切片標本像（1980年10月 7 日穿刺）。PAP（抗 IgM 血清）染色。陽性細胞が，洰胞梯增 殖巣辺縁部および周辺部にみられる。 $\times 100 。$ 

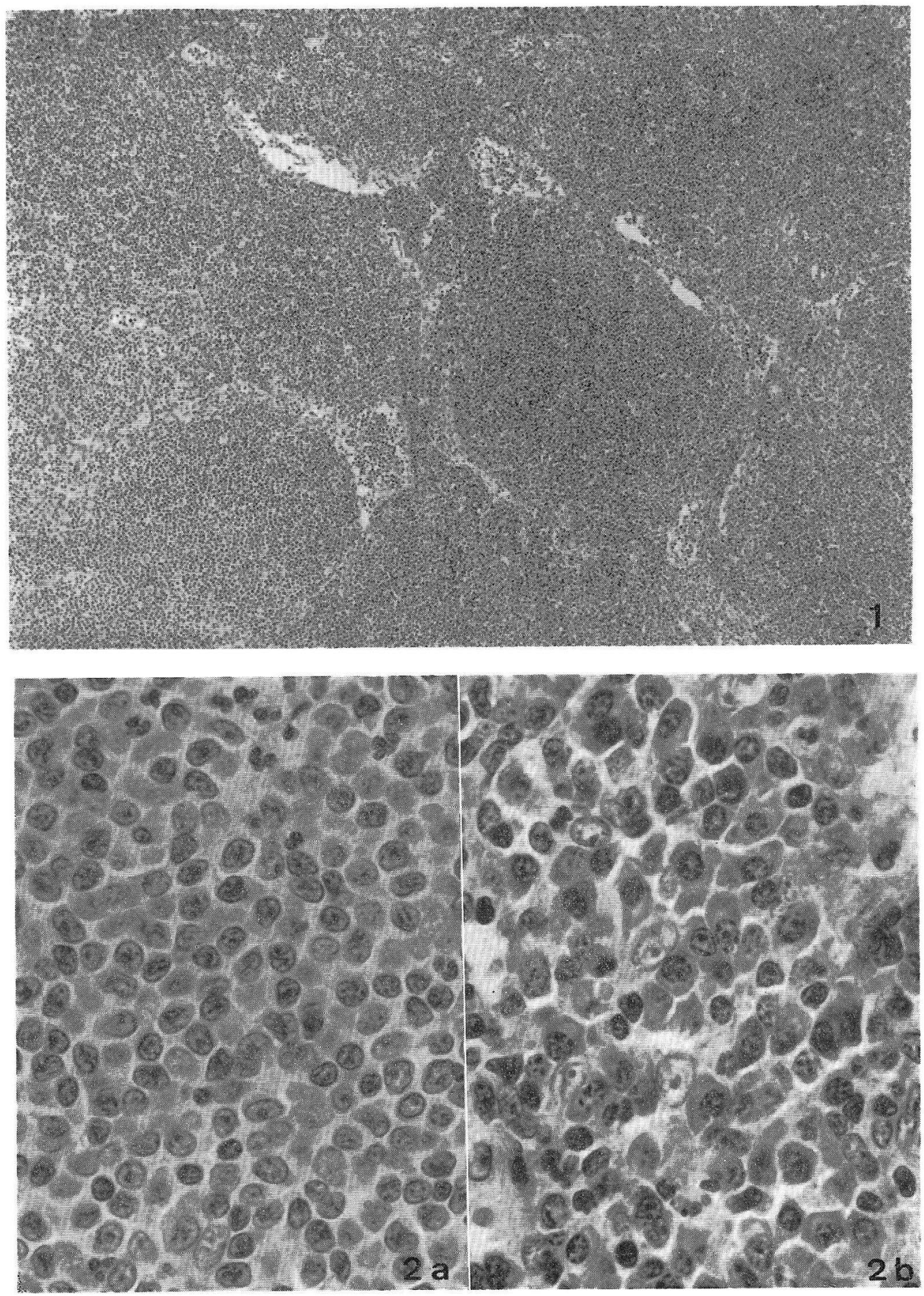
k. F.

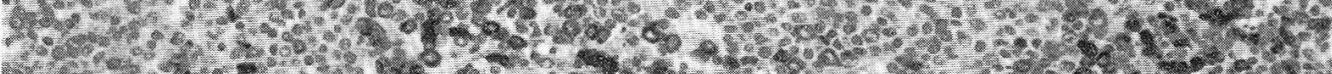

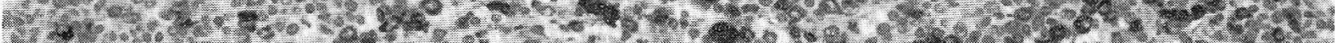

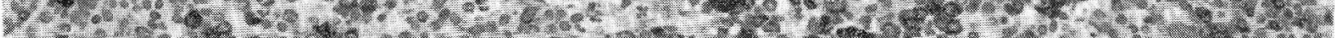

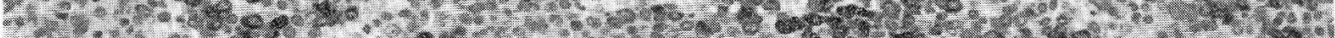

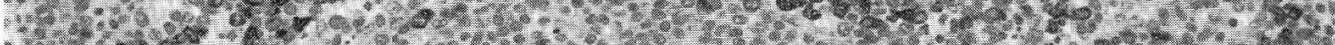

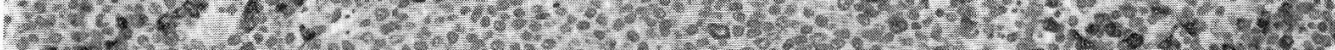

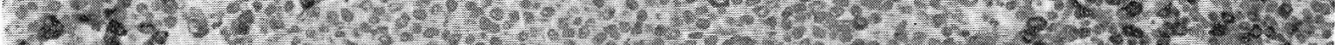

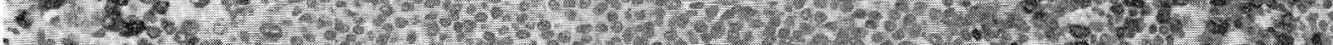
5.

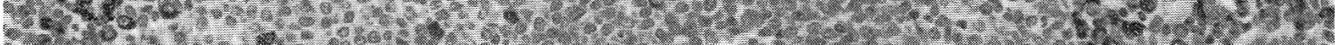

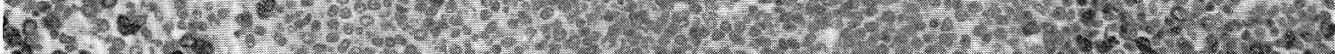
z.m.

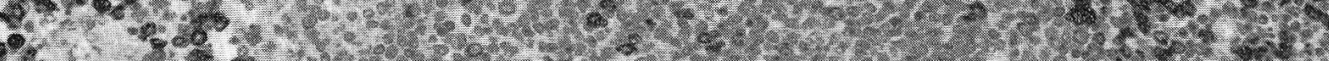

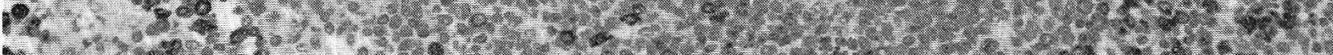

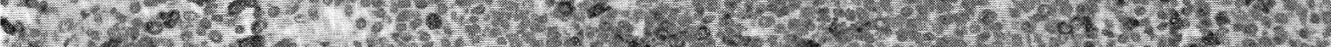

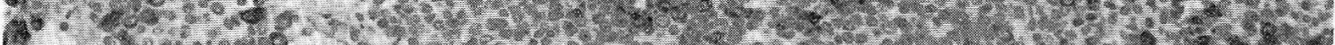
L

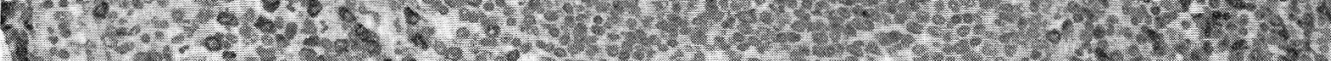

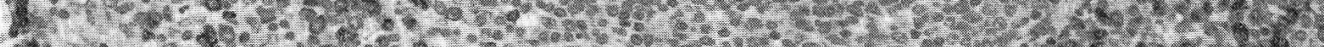

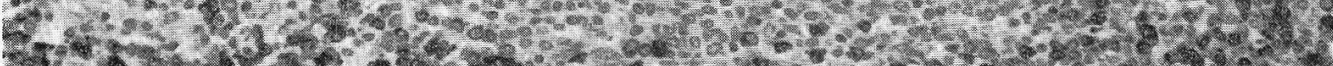

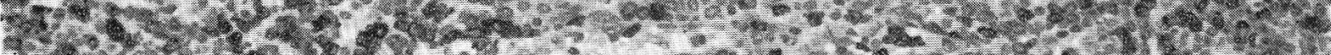

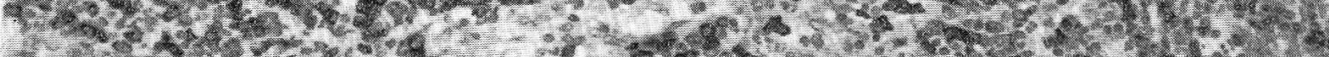

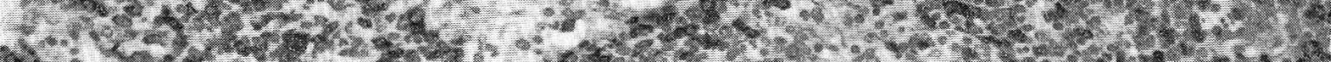

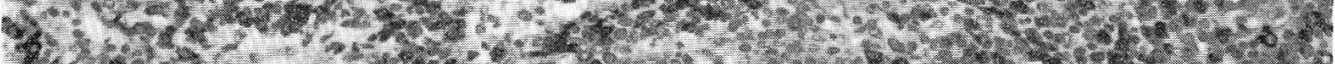

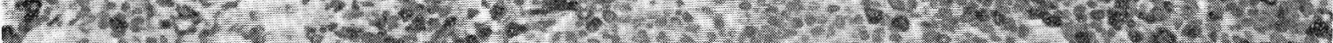

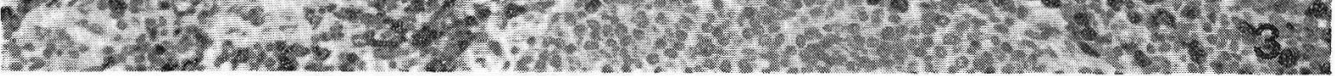

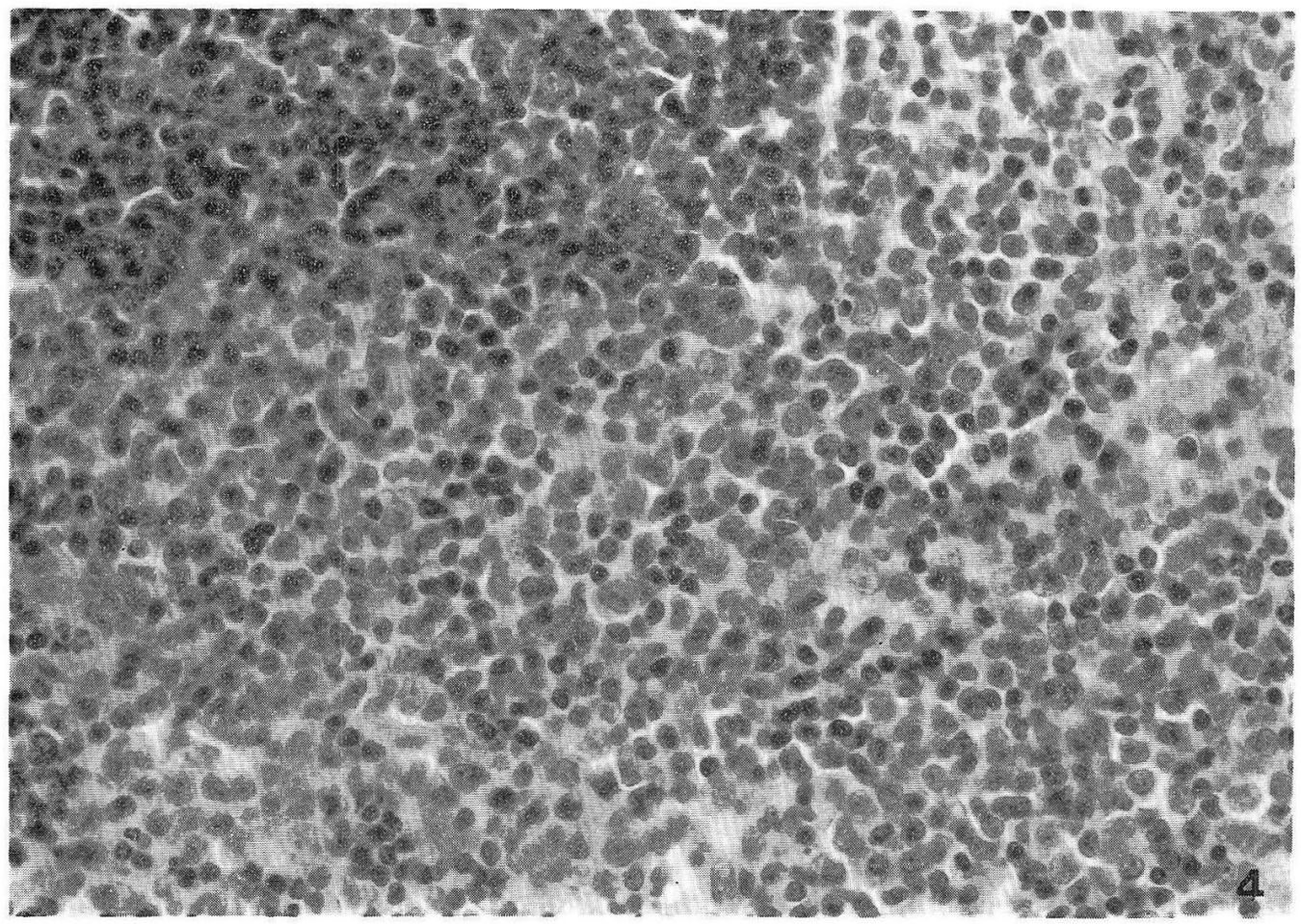



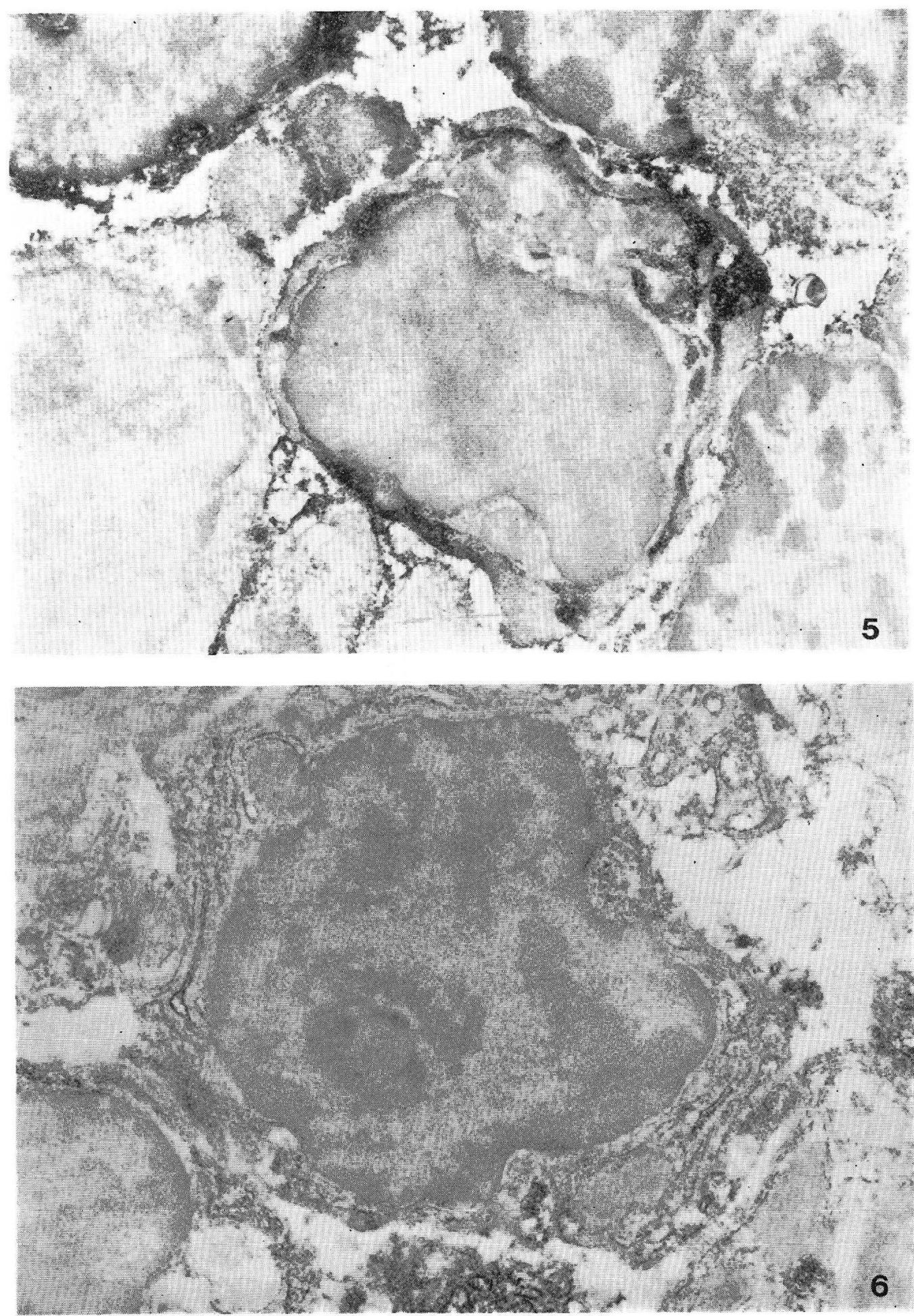

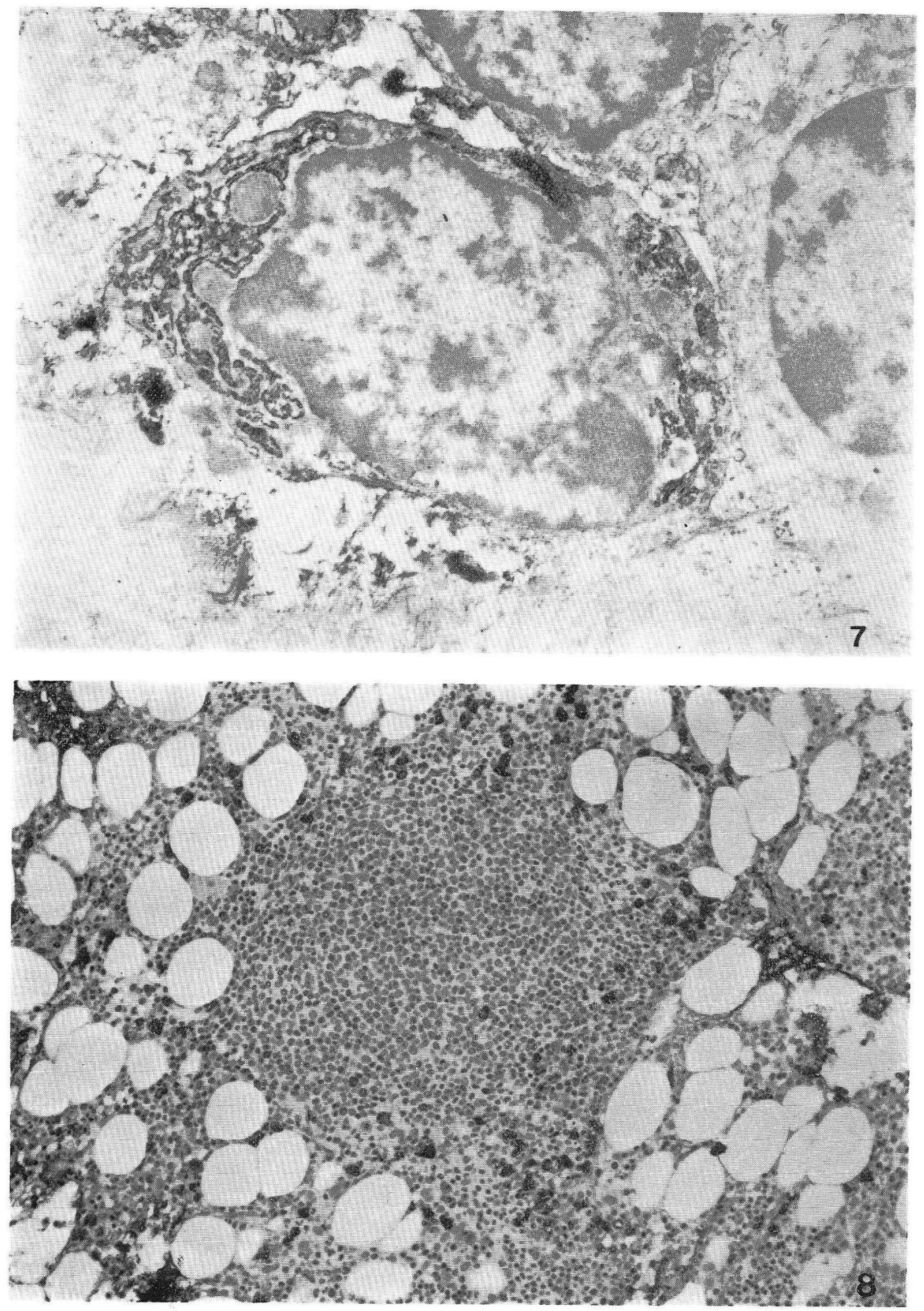